\title{
The Effect of the Purple Sweet Potato (Ipomoea Batatas L.) on the Fish Waste Silage Composition
}

\author{
Muhammad Zulfikar Fikri ${ }^{1}$, Zaenal Bachruddin ${ }^{1 *}$, Asih Kurniawati ${ }^{1}$ and Chusnul \\ Hanim $^{1}$
}

\author{
${ }^{1}$ Laboratory of Nutritional Biochemistry Faculty of Animal Science, Universitas Gadjah Mada Jalan Fauna No. 3, \\ Kampus UGM , Bulaksumur, Yogyakarta, Indonesia, 55281 Phone: (0274) 513363, 588688, EXT 73106/521578, \\ Mobile: +62 (0811255922) \\ *Corresponding author. Email: bachrudin@ugm.ac.id
}

\begin{abstract}
This study aims to determine the effect of adding different levels of purple sweet potato as a substrate for fermentation by Lactobacillus paracasei FDY 43 on the quality of fish waste silage at a low $\mathrm{pH}$ medium. The materials used in this study were fish waste (bycatch) and purple sweet potato flour. The study used L. paracasei FDY 43, which is lactic acid bacteria (LAB) from the collection of the Nutrition Biochemistry Laboratory, Faculty of Animal Science, Universitas Gadjah Mada. The level of purple sweet potato (S) used to observe the improvement of the quality of fish silage fermentation was 0; $2(\mathrm{Ks}) \_; 4(2 \mathrm{Ks})$; and 6\% (3 Ks). Parameters tested include crude protein and crude fat. The data obtained showed that the highest nutritional content of silage products was received at the addition of purple sweet potato levels as much as $2 \mathrm{Ks}$ and then analyzed with variance following a completely randomized design (CRD) in one direction. If there is a significant difference, Duncan's New Multiple Range Test (DMRT) is used for further analysis. The results showed that the different substrate levels of purple sweet potato as a treatment had a significant effect $(\mathrm{P}<0.05)$ on the increase in lactic acid, decrease in $\mathrm{pH}$, and crude protein. The conclusion from the results of this study was that differences in purple sweet potato substrate levels and low $\mathrm{pH}$ were able to maintain and improve the quality of fermented fish silage during storage.
\end{abstract}

Keywords: Fish Waste Silage, L. Paracasei FDY 43, Purple Sweet Potato, Crude Protein, Lactic Acid

\section{INTRODUCTION}

Bycatch fish is a commercial fish consisting of a mixture of various types of fish with a low quality (stale or damaged fish) so that they are not suitable for human consumption and have a low selling price. FAO [1] stated that bycatch fish is a commercial fish with low quality caused by poor handling or bad post-harvest practices used for industrial purposes that have low selling value. Many bycatches fish accumulate in the fish market and become waste contaminated by spoilage microorganisms, causing unpleasant odors and becoming a new problem. Bycatch fish is usually used as raw material for making salted fish, fish feed, and raw material for making fish flour. Fish flour is used as a source of animal protein for animal feed.

Besides being processed into fish flour, bycatch fish can also be processed into fish silage. Bycatch fish silage is a source of feed produced through the fermentation process of fish (whole or leftover) with the help of lactic acid bacteria. The advantages of making fish silage are increasing protein in feed ingredients and relatively easy to implement on a small or large scale. Handajani [2] stated that the fermentation could increase pure protein from $3.41 \%$ to $5.53 \%$ in feed sources.

Purple sweet potato (Ipomoea batatas L.) is one of the varieties that has the characteristics of a purple color on the tubers. The purple color of sweet potatoes appears caused anthocyanin pigments which have antioxidant properties. Haedersyah et al [3] stated that the carbohydrate source in the form of oligosaccharides found in sweet potatoes is a carbohydrate beneficial for the growth of probiotic bacteria. Arifin [4] noted that LAB growth in purple sweet potato extract medium had the highest total increase in LAB compared to white and yellow sweet potato varieties. Arfiani [5] stated that the inulin content of the purple sweet potato variety was $3.9 \%$ which had a higher percentage compared to the yellow sweet potato variety at $3.6 \%$ and the white 
sweet potato variety at $3.2 \%$. Therefore, the function of probiotics will be more optimal through the addition of prebiotics simultaneously to produce a product called synbiotic. The addition of purple sweet potato with the proper concentration as a source of prebiotics is expected to produce efficient fermentation products and improve feed quality, namely increasing the protein content of fresh fish silage due to the good symbiotic relationship between lactic acid bacteria and purple sweet potato, of science and technology in the field of animal husbandry.

\section{MATERIAL AND METHODS}

\subsection{Time and Location of the Research}

The research was conducted at the Nutritional Biochemistry Laboratory, Department of Animal Nutrition and Feed Science, Faculty of Animal Science, Universitas Gadjah Mada, Yogyakarta. The study was conducted for two months, from May to June 2021.

\subsection{Materials}

The tools that used in this research are stationery, digital scales, scissors, spoons, silica disk, oven $55^{\circ} \mathrm{C}$, oven $105^{\circ} \mathrm{C}$, newspapers, strapless, digital scales with a maximum capacity of $1000 \mathrm{~g}$ with an accuracy of 1 gram, desiccator, clamping pliers; furnace, incubator or oven, water bath, $\mathrm{pH}$ meter, filter paper, thermometer, refrigerator, centrifuge, pump pipette, micropipette, tip, Erlenmeyer tube, hange tube, tube rack, stirrer, beaker, bunsen, knife, filter, and blender.

The materials used were bycatch, purple sweet potato, and starter Lactobacillus paracasei from the collection of the Nutritional Biochemistry Laboratory, Faculty of Animal Science, UGM. The culture medium used to grow microbes was DeMan-Rogosa-Sharpe (MRS) agar. Chemicals for crude protein by the Kjeldahl method and crude fat by the Kamal method.

\subsection{Methods}

\subsubsection{Producing purple sweet potato flour}

Fresh purple sweet potato cleaned of dirt using running water. Purple sweet potatoes that have been cleaned then peeled and cut into small pieces. The purple sweet potato slices were baked at $55^{\circ} \mathrm{C}$ for 24 hours. After drying, the sweet potatoes are mashed using a blender until they become flour.

\subsubsection{Producing fresh fish silage at low $\mathrm{pH}$ medium}

Fresh bycatch fish was cleaned, then finely ground and placed in a bowl. Purple sweet potato flour with $0 \%$ feeding rate; $2 \% ; 4 \%$; and $6 \%$ as research treatment , $10 \%$ starter solid-state fermentation (SSF) $L$. paracasei and $3 \% 0.5 \mathrm{M}$ acetic acid solution of the total fish silage added and stirred. The mixture is then put into a vacuum plastic bag and sealed. Fermentation was carried out anaerobically at room temperature with a curing time of 0 and 21 days as a research treatment.

\subsubsection{Sample analysis}

Dry matter analysis. The dry matter was analyzed according to the AOAC method (2005). The sample is heated in an oven at $105^{\circ} \mathrm{C}$ for 8 to 24 hours, the water in the sample will evaporate while what is left is called dry matter [6].

Crude protein analysis. Samples were analyzed for crude protein by the Kjeldahl method. The principle of determination of crude protein content, according to AOAC (2005), concentrated sulfuric acid with a catalyst can break organic $\mathrm{N}$ bonds into (NH4)2SO4, which in alkaline conditions can release $\mathrm{NH} 3$, which is then titrated with $0.1 \mathrm{~N} \mathrm{HCl}$

Crude fat analysis. Determination of crude fat content according to Kamal 1997 Method. Fats can be extracted using ether or other fat solvents using a Soxhlet, then the ether is evaporated, and the weight of the fat can be known.

Table 1. Protein level (\%) of fermented fish silage

\begin{tabular}{|c|c|c|c|}
\hline \multirow{2}{*}{ Substrate Level (\%) } & \multicolumn{2}{|c|}{ Fermentation Day } & \multirow{2}{*}{ Average } \\
\cline { 2 - 4 } & 0 & $70.6 \pm 1.06^{\mathrm{c}}$ & $63.8 \pm 7.47^{\mathrm{p}}$ \\
\hline Control (0) & $57.1 \pm 0.84^{\mathrm{b}}$ & $74.2 \pm 1.91^{\mathrm{d}}$ & $64.5 \pm 10.7 \mathrm{p}$ \\
\hline 2 & $54.9 \pm 1.59^{\mathrm{ab}}$ & $79.2 \pm 0.78^{\mathrm{e}}$ & $66.3 \pm 14.1^{\mathrm{p}}$ \\
\hline 4 & $53.4 \pm 0.87^{\mathrm{a}}$ & $76.4 \pm 1.49^{\mathrm{d}}$ & $64.7 \pm 12.99$ \\
\hline 6 & $52.9 \pm 1.46^{\mathrm{a}}$ & $75.4 \pm 3.49^{\mathrm{s}}$ & \\
\hline Average & $54.6 \pm 1.99^{\mathrm{s}}$ & & \\
\hline
\end{tabular}


Table 2. Fat level (\%) of fermented fish silage

\begin{tabular}{|c|c|c|c|}
\hline \multirow{2}{*}{ Substrate Level (\%) } & \multicolumn{2}{|c|}{ Fermentation Day } & \multirow{2}{*}{ Average } \\
\cline { 2 - 4 } & 0 & $5.53 \pm 0.39^{\mathrm{ab}}$ & $5.66 \pm 0.33^{\mathrm{p}}$ \\
\hline Control (0) & $5.79 \pm 0.25^{\mathrm{ab}}$ & $6.73 \pm 0.27^{\mathrm{c}}$ & $6.19 \pm 0.62^{\mathrm{q}}$ \\
\hline 2 & $5.66 \pm 0.22^{\mathrm{ab}}$ & $6.42 \pm 0.23^{\mathrm{c}}$ & $5.91 \pm 0.58^{\mathrm{pq}}$ \\
\hline 4 & $5.40 \pm 0.12^{\mathrm{a}}$ & $5.93 \pm 0.10^{\mathrm{b}}$ & $5.85 \pm 0.15^{\mathrm{p}}$ \\
\hline 6 & $5.77 \pm 0.16^{\mathrm{ab}}$ & $6.15 \pm 0.53^{\mathrm{s}}$ & \\
\hline
\end{tabular}

\section{RESULTS AND DISCUSSION}

Fermentation of fish silage using fresh bycatch waste with the application of the addition of purple sweet potato as a prebiotic with three levels of addition, $\mathrm{n} 2 \%, 4 \%$, and $6 \%$ with $0 \%$ addition as control, $10 \%$ starter L. paracasei FDY 43, and $0.5 \mathrm{M}$ acetic acid as much as $3 \%$ of the total fermented silage of fish waste used. The addition of acetic acid serves as an acid treatment in fish silage. The mixture of feed ingredients is then cured in an airtight vacuum seal plastic for 21 days. The fermented fish silage was harvested and quality tested by proximate analysis, including dry matter, crude fat, and crude protein.

Crude Protein Level. Protein level in fermented fish silage was monitored on days 0 and 21, presented in Table 1. Differences in the substrate level of fermented fish silage significantly Fish waste silage's average crude protein level showed the highest yield at $6 \%$ substrate level, $66.3 \pm 14.1 \%$. For all substrate levels, the protein level at the end of the fermentation was higher than the protein level before the fermentation.

Protein in fish waste will undergo proteolysis by enzymes and produce peptides and amino acids. Lactobacillus paracasei uses proteins and peptides in fish waste silage as a source of $\mathrm{N}$, and a fermentation process occurs, thereby increasing crude protein levels in fish waste silage. Fermentation by Lactobacillus bacteria can break down bycatch into protein and further into amino acids (8) These amino acids will turn into $\mathrm{CO} 2, \mathrm{H} 2 \mathrm{O}$, lactic acid, acetic acid, ethanol, and nitrogen-containing compounds, namely NH3 (ammonia), which are alkaline, so the presence of NH3 can raise the $\mathrm{pH}$ slightly in the fermentation process.

Crude Fat level. Fat levels in fermented fish silage were measured on days 0 and 21, presented in Table 2 . Differences in the substrate level of fermented fish silage significantly affected fat level $(\mathrm{P}<0.05)$. Fish waste silage's average crude fat content showed the highest yield at a $2 \%$ substrate level, $6.19 \pm 0.62 \%$. The fat level at the end of the fermentation was higher than before for all substrate levels except the $0 \mathrm{Ks}$.

The increase in crude fat content was due to the use of carbohydrate sources as an energy source for lactic acid bacteria to grow, resulting in an increase in the number of lactic acid bacteria and causing the crude fat content in fish silage to increase. Setiadi [7] stated that in the fermentation process, the fat degradation process occurs. These fatty acids will then be used again by bacteria for growth so that there is a process of decreasing fat content in feed ingredients.

\section{CONCLUSION}

According to proximate analysis, using a substantial amount of purple sweet potato as a substrate resulted in silage of good quality. Furthermore, the highest nutritional content (protein content) of silage products was obtained by adding $2 \mathrm{Ks}$ of purple sweet potato.

\section{REFERENCES}

[1] FAO. 2005. The State of Food and Agriculture: Food and Agriculture Organization of The United Nations. TC IUU-CAP. Rome

[2] Handajani, H. 2014. Peningkatan kualitas silase limbah ikan secara biologis dengan memanfaatkan bakteri asam laktat. Jurnal GAMMA 9[2]:31-39.

[3] Haydersah, J., I. Chevallier., C. Rochette., C. Morquet-Rivier., T. Picq., C. Marianne-Pepin., C. Icard-Verniere, dan J. P. Guyot. 2012. Fermentation by amylolytic lactic acid bacteria and consequences for starch digestibility of plantain, breadfruit, and sweet potato flours. Journal of Food Science. 77[8]: 466-472.

[4] Arifin, M. Z. 2018. Pengaruh ekstrak ubi jalar [Ipomoea batatas L.] dari jenis dan konsentrasi yang berbeda terhadap pertumbuhan bakteri Bacillus sp D2.2. Skripsi Sarjana Pertanian. Universitas Lampung. Lampung.

[5] Arfiani, Y. F. 2016. Uji Beberapa Inulin Terhadap Beberapa Varietas Ubi Jalar [Ipomoea batatas L.] di Kabupaten Ngawi. Skripsi Sarjana Biologi. Universitas Islam Negeri Sunan Kalijaga. Yogyakarta. 
[6] Khumalawati, S. 2009. Pemanfaatan Limbah Kubis Menjadi Asam Laktat. Tugas Akhir. Jurusan Teknik Kimia, Fak. Teknik, Universitas Diponegoro, Semarang.

[7] Setiadi A.N.S. 2001. Mempelajari Penggunaan Cairan Pikel Ketimun sebagai Sumber Bakteri Asam Laktat pada Pembuatan Bekasam Ikan Tawes [Puntius javanicus]. Skripsi. Fakultas Perikanan dan Ilmu Kelautan, Institut Pertanian Bogor, Bogor 